\title{
Article \\ DASH Diet as a Proposal for Improvement in Cellular Immunity and Its Association with Metabolic Parameters in Persons with Overweight and Obesity
}

\author{
Carmen Paulina Rodríguez-López ${ }^{1}$, María Cristina González-Torres ${ }^{2}$, Carlos A. Aguilar-Salinas ${ }^{3}$ \\ and Oralia Nájera-Medina ${ }^{1, *}$ \\ 1 Departamento de Atención a la Salud, CBS, Universidad Metropolitano México-Xochimilco \\ (UAM-Xochimilco), Mexico City 04960, Mexico; cprl04@xanum.uam.mx \\ 2 Departamento de Ciencias de la Salud, CBS, Universidad Autónoma Metropolitano-Iztapalapa \\ (UAM-Iztapalapa), Mexico City 09340, Mexico; mcgt@xanum.uam.mx \\ 3 Departamento de Endocrinología y Metabolismo, Instituto Nacional de Ciencias Médicas y Nutrición \\ Salvador Zubirán (INCMNSZ), Mexico City 14080, Mexico; caguilarsalinas@yahoo.com \\ * Correspondence: onajera@correo.xoc.uam.mx; Tel.: +52-55-5483 7000 (ext. 2675)
}

Citation: Rodríguez-López, C.P.; González-Torres, M.C.;

Aguilar-Salinas, C.A.; Nájera-Medina, O. DASH Diet as a Proposal for Improvement in Cellular Immunity and Its Association with Metabolic Parameters in Persons with Overweight and Obesity. Nutrients 2021, 13, 3540. https://doi.org/ $10.3390 /$ nu13103540

Academic Editor: Lucia Malaguarnera

Received: 31 August 2021

Accepted: 5 October 2021

Published: 9 October 2021

Publisher's Note: MDPI stays neutral with regard to jurisdictional claims in published maps and institutional affiliations.

Copyright: (C) 2021 by the authors Licensee MDPI, Basel, Switzerland. This article is an open access article distributed under the terms and conditions of the Creative Commons Attribution (CC BY) license (https:/ / creativecommons.org/licenses/by/ $4.0 /)$.

\begin{abstract}
The development of obesity entails a chronic low-grade inflammatory state with increased pro-inflammatory cells, mainly in visceral adipose tissue (VAT). Additionally, dietary patterns have an influence on the regulation of chronic inflammation. Dietary Approaches to Stop Hypertension (DASH) include foods with an anti-inflammatory profile and that have positive impacts on body composition (BC), suggesting improvements in inflammatory processes. Objective: To analyze the impact of the DASH diet on cellular immunity, anthropometric, biochemical and BC parameters in patients with overweight and obesity, who could present metabolic syndrome. Methodology: Lymphocyte subpopulations, biochemical parameters, anthropometric parameters, and BC before and 8 weeks after intervention with the DASH diet in persons with overweight and obesity were measured. Results: Fifty-nine young adults participated in the study. After the intervention, no significant changes in biochemical parameters were observed, although a significant decrease in nearly all of the anthropometric and BC variables was found: waist circumference $(p<0.001)$, percentage and kilograms of fat $(p<0.001$ and $p<0.025$, respectively), VAT $(p<0.020)$, and weight $(p<0.001)$, as well as total lymphocytes and double-positive TCD4+ cells. A relation between changes in leukocyte subpopulations (monocytes, natural killer, helper and cytotoxic lymphocytes, and naive TCD4+ cells) and metabolic improvements (glucose, triglycerides, total cholesterol and LDL-c) was also found. Conclusions: The DASH diet promotes positive changes in lymphocyte subpopulations, anthropometric parameters and BC in persons with overweight and obesity. Future studies should elucidate the cellular and molecular mechanisms through which the DASH diet produces inmunometabolic improvement.
\end{abstract}

Keywords: obesity; chronic inflammation; dietary pattern

\section{Introduction}

Overweight $(\mathrm{OW})$ and obesity $(\mathrm{Ob})$ are considered a global public health problem as they increase the risk of developing metabolic syndrome (MS), type 2 diabetes, and cardiovascular diseases, among other alterations [1]. It has been observed that the development of obesity entails a chronic low-grade inflammatory state, which involves an increase in pro-inflammatory immune cells (neutrophils, lymphocytes TCD8, NK, B and macrophages type 1) in relation to anti-inflammatory cells (regulatory $\mathrm{T}$ lymphocytes and macrophages type 2) within adipose tissue (AT), mainly in visceral adipose tissue (VAT) [2-7].

Chronic inflammation has been demonstrated to have systemic consequences as it entails the production and secretion of pro-inflammatory cytokines and chemokines, which 
are, in turn, a by-product of the interaction between cells in the VAT. Cytokines and chemokines have endocrine effects that contribute to systemic insulin resistance when impacting on other organs (liver, pancreas and skeletal muscle) $[4,8-10]$, thus preceding cardiometabolic comorbidities related to obesity [2].

Effective actions are required to prevent the increase in obesity prevalence and to treat persons already affected by it. Lifestyle-based weight-loss programs, which include diets with caloric restriction and increased physical activity, are the most commonly employed methods [11]. Additionally, it has been demonstrated that the quality of feeding affects the inflammatory response of the immune system. A diet rich in fat, refined carbohydrates and protein is commonly associated with high levels of inflammation, while a diet rich in fruits, vegetables and fish is associated with low levels of inflammation or even anti-inflammatory patterns [12-14]. Therefore, dietary patterns exert an influence on the regulation of chronic inflammation, establishing diet as a factor that impacts inflammation in patients with obesity [11,15].

The Dietary Approaches to Stop Hypertension (DASH) diet is a dietary plan that includes foods rich in magnesium, potassium and calcium to stop and prevent arterial hypertension [16-18]. In addition, the DASH diet includes whole grains, fruits, vegetables, legumes, low-fat dairy products, poultry and fish, together with reduced amounts of saturated fat, cholesterol, red meat and refined grains and sweets [16,19-22]. Such foods included in the DASH diet are associated with a diet with an anti-inflammatory profile.

Some studies have implemented a DASH diet in persons with metabolic alterations, as in the case of MS [23]. The American Heart Association (AHA) even recommends this type of diet to prevent cardiovascular diseases [16,21,24]. Weight reduction has also been reported to be more significant in participants with $\mathrm{OW}$ and $\mathrm{Ob}$ who followed a low-calorie DASH diet than in those who followed other low-energy diets [25]. Therefore, the objective of this study was to analyze the impact of a DASH diet on cellular immunity, anthropometric, biochemical and body composition (BC) parameters in patients with $\mathrm{OW}$ and $\mathrm{Ob}$, who could present MS.

\section{Materials and Methods}

\subsection{Study Design}

A longitudinal and clinical trial study was performed with young adults, in Mexico City, Mexico. At baseline and after the intervention (8 weeks) with a DASH diet, analysis of the percentage of peripheral leukocyte subpopulations, anthropometric measurements, body composition (bioelectrical impedance analysis and dual-energy $\mathrm{X}$-ray absorptiometry) and biochemical tests were conducted.

\subsection{Eligibility Criteria}

Inclusion criteria: male and female adults aged 18 to 40, both genders. Exclusion criteria: individuals with any type of infection, pregnant, with TDM1 or T2DM, with autoimmune, hepatic, renal, endocrine or heart disease, cancer and those on medication. Elimination criteria: patients who did not sign the informed consent form, who decided to withdraw from the study, and who did not attend or were sick at their second evaluation. Participants provided written informed consent before participation. The study protocol was approved by the Local Ethics Committee of the Metropolitan Autonomous UniversityXochimilco, in Session 13/16, held on 1 December 2016, Mexico City, Mexico.

\subsection{Clinical Measurements}

\subsubsection{Anthropometric}

The assessed measurements included weight, height, and waist circumference (WC), following the standardized protocol of the International Society for the Advancement of Kinanthropometry (ISAK) [26]. A SECA 213 stadiometer set at a precision of $0.1 \mathrm{~cm}$ was used for the measurement of height. WC was measured utilizing a flexible and inextensible measuring tape (Lufkin); cutoffs are indicated by the Mexican Ministry of 
Health considering comorbidity risk factors (T2DM, hypertension and cardiovascular disease): men $\geq 90 \mathrm{~cm}$, women $\geq 80 \mathrm{~cm}$ [27]. Body mass index (BMI) was calculated as body mass divided by height squared $\left(\mathrm{kg} / \mathrm{m}^{2}\right)$. Participants were classified according to the World Health Organization [28] criteria for adults: normal weight: $18.5-24.99 \mathrm{~kg} / \mathrm{m}^{2}$, overweight: $25-29.99 \mathrm{~kg} / \mathrm{m}^{2}$, and obesity: $\geq 30 \mathrm{~kg} / \mathrm{m}^{2}$.

\subsubsection{Body Composition}

Body composition was assessed using the InBody720 multi-frequency impedance body composition analyzer with eight-point tactile electrodes equipment. Individuals with $\geq 100 \mathrm{~cm}^{2}$ of VAT were diagnosed as having visceral obesity (VAT increased), while those with $<100 \mathrm{~cm}^{2}$ were diagnosed as having normal VAT [29]. Weight was also measured with the equipment previously mentioned; all participants were assessed wearing light underwear. Percentage of subcutaneous fat (SF), skeletal muscle mass (SMM), and fat mass (FM) was measured using dual-energy X-ray absorptiometry (DXA; Hologic Discovery) and analyzed employing the Hologic APEX software, version 3.3.0.1.

\subsubsection{Biochemical Tests and Determination of Metabolic Syndrome}

Blood samples $(5 \mathrm{~mL})$ were collected in the morning and after a $12 \mathrm{~h}$ overnight fast. Triglycerides (TG), high-density cholesterol (HDL-c), fasting glycemia (Glu), and total cholesterol (Total Cho) were measure with an automated IKEM clinical chemistry analyzer. Low-density cholesterol (LDL-c) was calculated with the Friedewald formula.

Systolic and diastolic blood pressure were measured twice in each patient using a sphygmomanometer with the patient in a semi-reclined position after a rest period, according to the guidelines of the Mexican Official Norm [30] for the Prevention, Treatment, and Control of Hypertension.

The presence of metabolic syndrome (MS) was determined according to the definition of the Cholesterol Education National Program (ATP III), modified for Hispanic people. These guidelines suggest that MS should be considered when there is an association of at least three of the conditions included in Table 1.

Table 1. ATP III criteria modified for the Hispanic population.

\begin{tabular}{|c|c|c|}
\hline Criteria & \multicolumn{2}{|c|}{ Values } \\
\hline Triglycerides & \multicolumn{2}{|c|}{$\geq 150 \mathrm{mg} / \mathrm{dL}$} \\
\hline HDL-c & \multicolumn{2}{|c|}{$<40 \mathrm{mg} / \mathrm{dL}$} \\
\hline Blood pressure & \multicolumn{2}{|c|}{$\geq 130 / 85 \mathrm{mmHg}$ or previous diagnosis } \\
\hline Fasting glucose & \multicolumn{2}{|c|}{$\geq 100 \mathrm{mg} / \mathrm{dL}$} \\
\hline Waist circumference & $\begin{array}{l}\text { Women } \\
\geq 80 \mathrm{~cm}\end{array}$ & $\begin{array}{c}\text { Men } \\
\geq 90 \mathrm{~cm}\end{array}$ \\
\hline
\end{tabular}

HDL-c: high-density cholesterol. Adapted from: [31].

\subsubsection{Leukocyte Measurement}

A second venous blood sample $(5 \mathrm{~mL})$ was obtained from patients in order to identify leukocyte subpopulations. Leukocytes were stained using anti-human monoclonal antibodies conjugated to fluorescein (FITC), phycoerythrin (PE), the peridinin-chlorophylla protein (PerCP), and/or allophycocyanin (APC). Combinations of conjugated monoclonal antibodies were used as follows: FITC-anti-CD45/Pe-anti-CD14; FITC-anti-CD3/PE-antiCD16+CD56/PerCP-anti-CD19; FITC-anti-CD4/PE-anti-CD62/PerCP-anti-CD3; FITC-antiCD8/PE-anti-CD28/PerCP-anti-CD3; and FITC-anti-CD45RA/PE-anti-CD45RO/PerCPanti-CD4/APC-anti-CD3. Percentages of total lymphocytes, monocytes and granulocytes were obtained through the first combination; TCD3+ lymphocytes, NK, and B with the second combination; TCD4+ lymphocytes, helper cells (TCD4+CD62-) and TCD3+ were obtained through the third one; TCD8+ lymphocytes, cytotoxic cells (TCD8+CD28-) and TCD3+ through the fourth one; and memory (CD45RO+) and naive (CD45RA+) cells of TCD3+ and TCD4+ through the last one. Cells were incubated with antibodies under conditions of darkness for $20 \mathrm{~min}$. Then, $3 \mathrm{~mL}$ of lysis solution was added and incubated 
for $10 \mathrm{~min}$. After washing, cells were fixed with $1 \% p$-formaldehyde and stored under conditions of darkness until analyzed through flow cytometry (within the first $24 \mathrm{~h}$ ) [32,33].

Sample analysis was performed using a FACSCanto II Cytometer with FACSDiva software (BD Biosciences, San Jose, CA, USA); 10,000 cells were counted in each sample. Two fluorescence dual-axis graphs were constructed.

\subsection{Intervention}

The dietary plan was based on the DASH diet, utilizing its percentages of macronutrient distributions as follows: $55 \%$ carbohydrates; $27 \%$ lipids, and $18 \%$ proteins. This diet also takes into consideration the specific parameters of sodium, potassium, calcium, and magnesium; however, in the present work, these were not considered quantitatively: patients were only advised to prefer foods that contained these micronutrients, and they were offered a list of these nutriments.

The calculation of total energy had, as its objective, a weight reduction of $500 \mathrm{~g}$ per week. To achieve this objective, the total energy requirement was calculated using the Food and Agricultural Organization/World Health Organization (FAO/WHO) equation of 2004, to which kilocalories (Kcal) obtained from a Food Consumption Frequency (FCC) questionnaire of each patient, designed for the Mexican population, were added [34,35]. The average was calculated and $500 \mathrm{Kcal}$ were subtracted from this number [36].

A diet plan, personalized to the highest extent possible, was carried out in order to achieve the highest adherence of the patient. Follow-up through the patient's subsequent appointments was carried out every $2-3$ weeks, according to the performance of each patient.

For the elaboration of the dietary plan, work was conducted based on the Sistema Mexicano de Alimentos Equivalentes (SMAE, Mexican System of Food Equivalents) [37]. The number of grams of each macronutrient was transformed into food rations distributed among each of the food groups. Regarding calories specific to each individual, its distribution among different food groups was adapted according to the following general recommendation ( $2000 \mathrm{kcal} /$ day diet): $6-8$ portions of whole grains, 4-5 fruits and vegetables, about 7 carbohydrates, 2 or less lean meat products and 2-3 portions of skimmed dairy products. Dehydrated fruits, seeds, and legumes were to be ingested at least 4 times a week $[16,38]$. The sodium content of the DASH diet was designed to be less than $2400 \mathrm{mg} /$ day [39]. The distribution of the rations had, as its final purpose, the achievement of distributing these in three main meals (breakfast, lunch, and dinner) and in two snacks (morning and evening).

To achieve adherence, participants were oriented through the benefits of a healthy diet (for example, the incorporation of fruits, vegetables, whole grains, etc.) and food portions. They were provided with practical guidelines that aided them in selecting foods that were appropriate for their diet. Participants were also supported in elaborating a menu based on their dietary habits and in compliance with the DASH diet guidelines.

\subsection{Statistical Analysis}

The Shapiro-Wilk test was utilized to determine whether the variables presented had a Gaussian distribution. Logarithmic transformation was performed to approximate normality in variables without Gaussian distribution. The results are presented as mean \pm standard deviation (SD) and the median, with the interquartile range (IQR, 25-75). Comparisons between baseline conditions and those present after the intervention were conducted with a Student $t$ test for paired samples. One-way ANOVA was applied to determine differences among $>2$ groups as well as Bonferroni post hoc tests to find out among which groups differences were present. Data were adjusted by sex and age. A $p$ value of $<0.05$ was considered significant, using the SPSS ver. 21 statistical software program.

\section{Results}

In the present study, 80 persons were initially incorporated; however, due to individual circumstances, 13 withdrew, 5 did not attend the second evaluation, and 3 more were 
sick at their second evaluation; therefore, these participants were eliminated from the study (Figure 1).

In the analysis, 59 subjects were included and distributed in two groups: the control group and the study group. The former included 29 participants with normal body mass index (BMI) and VAT, without MS (individuals who did not follow a food plan), and paired by sex and age with the study group. The latter included 30 persons with $\mathrm{OW}$ and $\mathrm{Ob}$, who adhered to a dietary plan for weight reduction (Figure 1). The mean age of all participants was $25.9 \pm 6.5$ years. Ninety percent of participants were female.

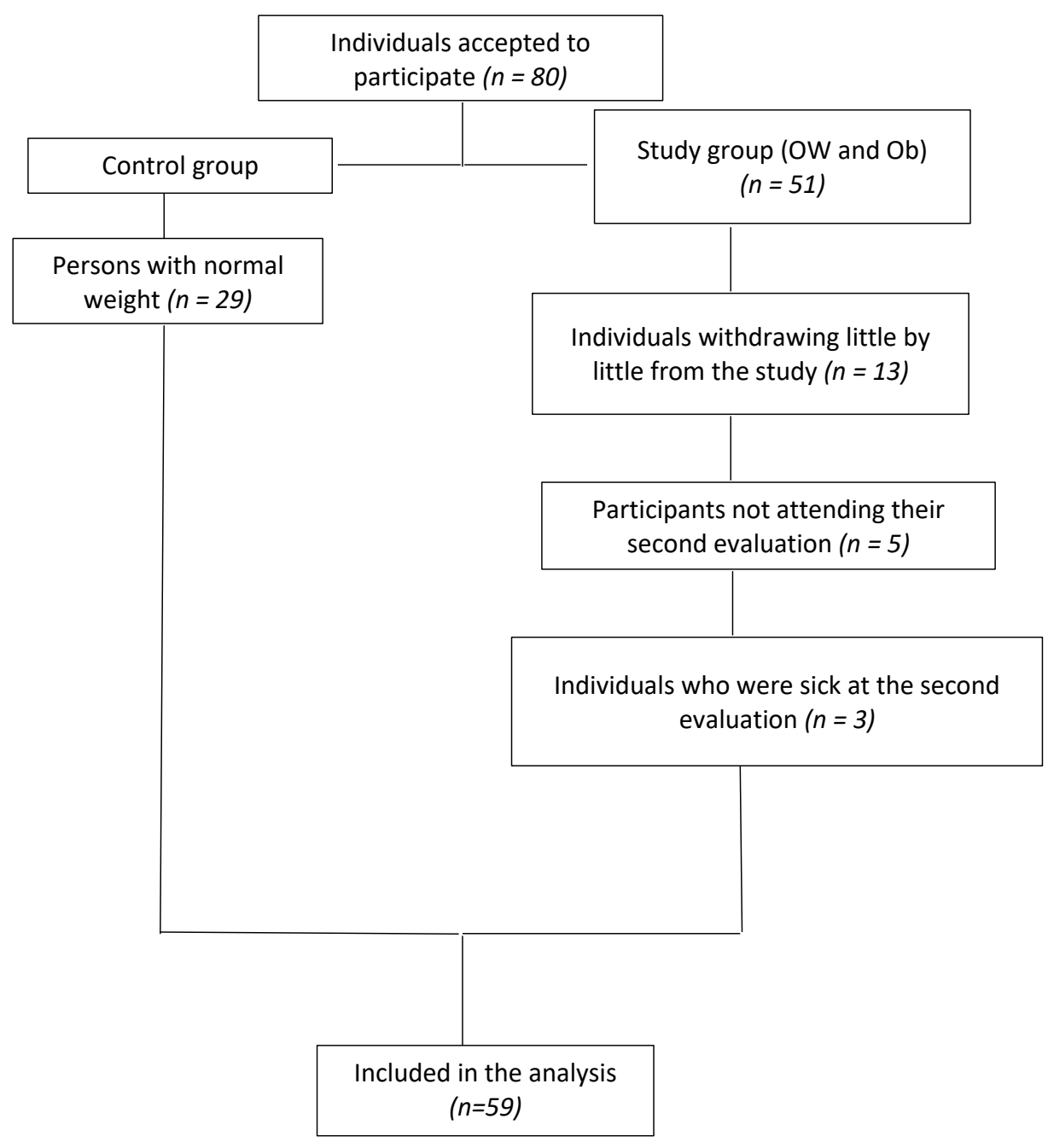

Figure 1. Distribution of the population along the study period.

\subsection{Baseline Characteristics}

Of the total number of subjects included in the study $(n=59), 49 \%(n=29)$ had a normal BMI, $24 \%(n=14)$ had OW, and $27 \%(n=16)$ had Ob. On the other hand, a prevalence of only $13 \%(n=4)$ MS was found in persons with OW and Ob. Likewise, it was observed that persons with $\mathrm{Ob}$ and MS in their majority presented increased VAT.

\subsection{Laboratory Analysis, Anthropometric Parameters, and Body Composition}

When biochemical variables were analyzed, it was observed that persons with $\mathrm{Ob}$ presented higher glucose values than individuals with OW. In addition, in persons with OW and $\mathrm{Ob}$, high-density lipoprotein-cholesterol (HDL-c) was found to be low, while diastolic and systolic arterial pressure were high. Compared with normal weight participants, all these differences were statistically significant (Table 2). 
Regarding anthropometric and BC measurements, persons with normal weight exhibited the lowest values in waist circumference (WC), subcutaneous adipose tissue (ST), body fat mass (BFM), and VAT, in comparison with persons with OW and Ob. All these differences were significant (Table 2).

Table 2. Biochemical indicators, anthropometric measurements and body composition according to BMI, before and after 2 months of the dietary plan.

\begin{tabular}{|c|c|c|c|c|c|c|c|c|c|}
\hline \multirow{2}{*}{$\begin{array}{c}\text { Variable } \\
(n=59)\end{array}$} & \multirow[t]{2}{*}{$\begin{array}{l}\text { Normal } \\
(n=29)\end{array}$} & \multicolumn{3}{|c|}{$\begin{array}{l}\text { Overweight } \\
(n=14)\end{array}$} & \multicolumn{3}{|c|}{$\begin{array}{l}\text { Obesity } \\
(n=16)\end{array}$} & \multicolumn{2}{|c|}{$p$ (ANOVA) } \\
\hline & & B & $\mathbf{A}$ & $p^{\#}$ & B & A & $p^{\#}$ & $p$ & $\begin{array}{c}p \\
\text { (post hoc) }\end{array}$ \\
\hline TG $(\mathrm{mg} / \mathrm{dL})$ & $90.7 \pm 38.1$ & $\begin{array}{c}101.5 \\
(69.2-131.5)\end{array}$ & $\begin{array}{c}112 \\
(89.4-138.2)\end{array}$ & 0.867 & $\begin{array}{c}99 \\
(77.7-126.7)\end{array}$ & $\begin{array}{c}115.6 \\
(77.1-145.5)\end{array}$ & 0.280 & 0.200 & \\
\hline c-HDL (mg/dL) & $50.1 \pm 11.6$ & $33.9 \pm 7.4^{*}$ & $\begin{array}{c}36.9 \\
(34.4-39.5)\end{array}$ & 0.327 & $35.9 \pm 7.5^{*}$ & $\begin{array}{c}35.5 \\
(34-36.8)\end{array}$ & 0.824 & 0.000 & 0.000 \\
\hline Glu (mg/dL) & $78.9 \pm 8.3$ & $73.3 \pm 13$ & $82.1 \pm 10.3$ & 0.107 & $85.5 \pm 12.3^{\&}$ & $82.1 \pm 7.6$ & 0.370 & 0.011 & 0.009 \\
\hline c-LDL (mg/dL) & $70.4 \pm 30$ & $70 \pm 16.1$ & $72.4 \pm 41.3$ & 0.826 & $90.1 \pm 33.8$ & $75.8 \pm 37.7$ & 0.154 & 0.070 & \\
\hline TCho (mg/dL) & $138.7 \pm 34.4$ & $\begin{array}{c}134 \\
(104.4-143.9)\end{array}$ & $131.4 \pm 41.3$ & 0.439 & $\begin{array}{c}143 \\
(124-166.1)\end{array}$ & $134.7 \pm 40.3$ & 0.111 & 0.274 & \\
\hline $\mathrm{SBP}(\mathrm{mmHg})$ & $101.7 \pm 11$ & $\begin{array}{c}105 \\
(100-112.5)\end{array}$ & $\begin{array}{c}100 \\
(100-116.2)\end{array}$ & 0.919 & $\begin{array}{c}110 \\
(110-120) *\end{array}$ & $\begin{array}{c}110 \\
(100-120)\end{array}$ & 0.070 & 0.003 & 0.002 \\
\hline $\mathrm{DBP}(\mathrm{mmHg})$ & $69.5 \pm 7$ & $\begin{array}{c}70 \\
(67.5-72.5)\end{array}$ & $70(70-76.2)$ & 0.328 & $\begin{array}{c}70 \\
(70-80) *\end{array}$ & $\begin{array}{c}80 \\
(70-80)\end{array}$ & 0.855 & 0.010 & 0.008 \\
\hline Weight (kg) & $55.5 \pm 8.3$ & $66.8 \pm 7.2 *$ & $64.8 \pm 7.2^{\#}$ & 0.001 & $85.2 \pm 10^{*, \&}$ & $82.4 \pm 9.4^{\#}$ & 0.001 & 0.000 & 0.000 \\
\hline $\begin{array}{c}\mathrm{BMI} \\
\left(\mathrm{kg} / \mathrm{m}^{2}\right)\end{array}$ & $21.3 \pm 2.1$ & $26.8(26.4-27.3)$ * & $\begin{array}{c}25.7 \\
(25.1-26.7)^{\#}\end{array}$ & 0.001 & $31.9(30.6-35.9) *$ * & $\begin{array}{c}31.7 \\
(29.7-34.7)\end{array}$ & 0.003 & 0.000 & 0.000 \\
\hline WC $(\mathrm{cm})$ & $78.4 \pm 9.3$ & $89.5 \pm 8^{*}$ & $84.1 \pm 6.3^{\#}$ & 0.000 & $102.4 \pm 8.7^{* \& \&}$ & $96.8 \pm 10.3^{\#}$ & 0.001 & 0.000 & 0.000 \\
\hline SMM (kg) & $31.5 \pm 6.2$ & $35.4 \pm 7.8$ & $35.6 \pm 8.1$ & 0.874 & $41.1 \pm 7^{*}$ & $40.3 \pm 6.9$ & 0.083 & 0.000 & 0.000 \\
\hline ST $(\%)$ & $32.3 \pm 5.2$ & $40.7 \pm 5.5^{*}$ & $39.6 \pm 5.4^{\#}$ & 0.038 & $46.1 \pm 5.1^{*, \&}$ & $45.1 \pm 5.1^{\#}$ & 0.021 & 0.000 & 0.000 \\
\hline $\mathrm{BFM}(\mathrm{kg})$ & $16.4 \pm 3.7$ & $26.3 \pm 3.6^{*}$ & $25.2 \pm 4.1^{\#}$ & 0.025 & $38.6 \pm 5.8^{*, \&}$ & $36.3 \pm 5.7^{\#}$ & 0.001 & 0.000 & 0.000 \\
\hline $\operatorname{VAT}\left(\mathrm{cm}^{2}\right)$ & $61 \pm 21.4$ & $111.3 \pm 22.3 *$ & $106.3 \pm 24.6^{\#}$ & 0.020 & $174 \pm 38.6^{*, \&}$ & $161 \pm 34.6^{\#}$ & 0.000 & 0.000 & 0.000 \\
\hline
\end{tabular}

B: before; A: after; TG: triglycerides; c-HDL: high-density lipoprotein cholesterol, Glu: glucose; c-LDL: Low-density cholesterol; TCho: total cholesterol; SBP: systolic blood pressure; DBP: diastolic blood pressure; BMI: body mass composition; WC: waist circumference; SMM: skeletal muscle mass; ST: subcutaneous adipose tissue; BFM: body fat mass; VAT: visceral adipose tissue. Data are presented in media \pm SD or median and interquartile interval (IIC). $p$ (post hoc): $p$ value adjusted with Bonferroni test. \# Statistically significant difference between before and after. * Statistically significant difference vs. normal. \& Statistically significant difference vs. overweight $(p<0.05)$.

\subsection{Leukocytes Subpopulation}

With respect to lymphocyte subpopulations, it was found that monocytes and naïve TCD3+ (TCD3+CD45RA+) cells decreased as BMI increased; therefore, persons with $\mathrm{Ob}$ had the lowest values, while persons with normal weight, the highest. On the other hand, the percentage of NK cells was lower in persons with OW. In terms of TCD8+ cells, it was found that persons with $\mathrm{Ob}$ had the lowest values in comparison with persons with OW. The lowest percentages of naïve TCD3+ and TCD4+ (CD45RA+) cells and the highest percentages of memory cells (TCD3+CD45RO+ and TCD4+CD45RO+) were observed in individuals with $\mathrm{OW}$ and $\mathrm{Ob}$. All these differences were significant (Table 3).

Table 3. Leukocyte distribution before and after of dietary plan according to BMI.

\begin{tabular}{|c|c|c|c|c|c|c|c|c|c|}
\hline \multirow{2}{*}{$\begin{array}{c}\text { Variable } \\
(n=59) \\
(\%)\end{array}$} & \multirow[t]{2}{*}{$\begin{array}{l}\text { Normal } \\
(n=29)\end{array}$} & \multicolumn{3}{|c|}{$\begin{array}{l}\text { Overweight } \\
(n=14)\end{array}$} & \multicolumn{3}{|c|}{$\begin{array}{l}\text { Obesity } \\
(n=16)\end{array}$} & \multicolumn{2}{|c|}{$p$ (ANOVA) } \\
\hline & & B & $\mathbf{A}$ & $p^{\#}$ & B & $\mathbf{A}$ & $p^{\#}$ & $p$ & $\begin{array}{c}p \\
\text { (post hoc) }\end{array}$ \\
\hline Total Lymphocytes & $30.2 \pm 9.7$ & $\begin{array}{c}29.9 \\
(27.8-40.9)\end{array}$ & $26.1 \pm 8.2^{\#}$ & 0.019 & $\begin{array}{c}30.3 \\
(27.4-32.4)\end{array}$ & $31.1 \pm 8.6$ & 0.798 & 0.600 & \\
\hline Monocytes & $\begin{array}{c}8.3 \\
(6.5-9.9)\end{array}$ & $7.7 \pm 2.3$ & $\begin{array}{c}7.3 \\
(6.6-8)\end{array}$ & 0.636 & $6.4 \pm 2 *$ & $\begin{array}{c}7.4 \\
(6.9-8.3)\end{array}$ & 0.061 & 0.017 & 0.014 \\
\hline Granulocytes & $\begin{array}{c}63.9 \\
(56.5-69.3)\end{array}$ & $\begin{array}{c}61.5 \\
(53.1-66.3)\end{array}$ & $66.6 \pm 7.6^{\#}$ & 0.016 & $\begin{array}{c}62.7 \\
(61-66.2)\end{array}$ & $60.9 \pm 8.5$ & 0.530 & 0.560 & \\
\hline Lymphocytes B (CD19) & $\begin{array}{c}12.7 \\
(7.1-23.1)\end{array}$ & $\begin{array}{c}14.8 \\
(10-23.4)\end{array}$ & $\begin{array}{c}15.4 \\
(9.9-19.1)\end{array}$ & 0.635 & $\begin{array}{c}13.7 \\
(9.4-23.2)\end{array}$ & $\begin{array}{c}9.3 \\
(7.9-16)\end{array}$ & 0.052 & 0.384 & \\
\hline $\begin{array}{c}\text { Lymphocytes NK } \\
\text { (CD16CD56) }\end{array}$ & $20.4 \pm 8.6$ & $14.3 \pm 5.1^{*}$ & $\begin{array}{c}10.9 \\
(7.5-17.6)\end{array}$ & 0.253 & $17.2 \pm 5.9$ & $\begin{array}{c}13.3 \\
(8.9-23.9)\end{array}$ & 0.413 & 0.036 & 0.041 \\
\hline Lymphocytes T CD3+ & $63.7 \pm 12.7$ & $68.2 \pm 8.7$ & $71.4 \pm 8.4$ & 0.128 & $65.6 \pm 10.3$ & $72.1 \pm 9.3^{\#}$ & 0.012 & 0.456 & \\
\hline Lymphocytes T CD4+ & $52.4 \pm 11.5$ & $51.9 \pm 7.5$ & $53.5 \pm 6.8$ & 0.217 & $56.2 \pm 10.6$ & $54.2 \pm 10.9$ & 0.455 & 0.506 & \\
\hline $\mathrm{CD} 4+\mathrm{CD} 62-$ & $29.1 \pm 10$ & $46.4 \pm 18.3 *$ & $41.2 \pm 13.5$ & 0.538 & $36 \pm 24.7$ & $40.1 \pm 15.5$ & 0.644 & 0.053 & 0.058 \\
\hline Lymphocytes T CD8+ & $33.4 \pm 9$ & $39.4 \pm 13.7$ & $32.6 \pm 6.5$ & 0.143 & $23.9 \pm 6.5^{\&}$ & $23.5 \pm 9.3$ & 0.871 & 0.035 & 0.031 \\
\hline CD8+CD28- & $31.7 \pm 12.9$ & $34.8 \pm 20.5$ & $32 \pm 12.9$ & 0.700 & $25.8 \pm 16.2$ & $22.4 \pm 9.6$ & 0.476 & 0.587 & \\
\hline $\mathrm{CD} 3+\mathrm{CD} 45 \mathrm{RA}+$ & $\begin{array}{c}53.8 \\
(43.6-61)\end{array}$ & $36.8 \pm 12.9^{*}$ & $39.4 \pm 11.3$ & 0.199 & $35.5 \pm 12.3^{*}$ & $35.5 \pm 12.4$ & 0.988 & 0.000 & 0.003 \\
\hline
\end{tabular}


Table 3. Cont.

\begin{tabular}{|c|c|c|c|c|c|c|c|c|c|}
\hline \multirow{2}{*}{$\begin{array}{c}\text { Variable } \\
(n=59) \\
(\%)\end{array}$} & \multirow[t]{2}{*}{$\begin{array}{l}\text { Normal } \\
(n=29)\end{array}$} & \multicolumn{3}{|c|}{$\begin{array}{l}\text { Overweight } \\
(n=14)\end{array}$} & \multicolumn{3}{|c|}{$\begin{array}{l}\text { Obesity } \\
(n=16)\end{array}$} & \multicolumn{2}{|c|}{$p$ (ANOVA) } \\
\hline & & B & $\mathbf{A}$ & $p^{\#}$ & B & $\mathbf{A}$ & $p^{\#}$ & $p$ & $\begin{array}{c}p \\
\text { (post hoc) }^{*, \&}\end{array}$ \\
\hline CD3+CD54RO+ & $32.5 \pm 9.5$ & $45.6 \pm 10.9^{*}$ & $44.2 \pm 8.2$ & 0.380 & $40.1 \pm 13$ & $42.7 \pm 11.3$ & 0.327 & 0.006 & 0.008 \\
\hline $\begin{array}{c}\mathrm{CD} 3+ \\
\mathrm{CD} 45 \mathrm{RA}+\mathrm{CD} 45 \mathrm{RO}+\end{array}$ & $13.6 \pm 4.1$ & $17.7 \pm 6.8$ & $\begin{array}{c}14.8 \\
(11-18.1)\end{array}$ & 0.236 & $18.8 \pm 7.7^{*}$ & $\begin{array}{c}18.7 \\
(14.4-25.6)\end{array}$ & 0.494 & 0.054 & 0.080 \\
\hline $\begin{array}{c}\text { CD4+ } \\
\text { CD45RA+ }\end{array}$ & $41.5 \pm 10.1$ & $24.8 \pm 10.6^{*}$ & $28.1 \pm 13$ & 0.183 & $26.2 \pm 8.2 *$ & $26.9 \pm 10.2$ & 0.791 & 0.000 & 0.000 \\
\hline $\begin{array}{c}\mathrm{CD} 4+ \\
\mathrm{CD} 45 \mathrm{RO}+\end{array}$ & $40.7 \pm 10.6$ & $60.1 \pm 11.2$ * & $60.3 \pm 12.7$ & 0.944 & $51.9 \pm 12.5^{*}$ & $58.9 \pm 12.3^{\#}$ & 0.016 & 0.000 & 0.000 \\
\hline $\begin{array}{c}\mathrm{CD} 4+ \\
\mathrm{CD} 45 \mathrm{RA}+\mathrm{CD} 45 \mathrm{RO}+\end{array}$ & $14.1 \pm 5.2$ & $14 \pm 3.9$ & $\begin{array}{c}11.1 \\
(7.8-14.3)\end{array}$ & 0.092 & $17.6 \pm 5.8$ & $\begin{array}{c}11.8 \\
(8.6-18.5)^{\#}\end{array}$ & 0.034 & 0.114 & \\
\hline
\end{tabular}

B: before; A: after. Data are presented in media \pm SD or median and interquartile interval (IIC). $p$ (post hoc): $p$ value adjusted with Bonferroni test. " Statistically significant difference between before and after. ${ }^{*}$ Statistically significant difference vs. normal. \& Statistically significant difference vs. overweight $(p<0.05)$.

\subsection{Implementation of a Dietary Plan for Metabolic and Immunological Improvement}

In Figure 2, changes in biochemical indicators of participants, before and after implementation of a dietary plan, are presented, without these being statistically significant. However, when biochemical variables were analyzed in each participant with $\mathrm{OW}$ and $\mathrm{Ob}$, it was observed that triglycerides (TG) decreased in 33\% of participants by $48.6 \pm 15 \%$, glucose in $50 \%$ by $11.5 \pm 8.6 \%$, total cholesterol in $60 \%$ of individuals by $30.5 \pm 18.8 \%$, low-density lipoprotein-cholesterol (LDL-c) in $60 \%$ by $34.6 \pm 17.3 \%$, and HDL-c increased in $56 \%$ of individuals by $6.9 \pm 4.4 \%$ (data not shown). These results were not observed when analyzing these variables by group.
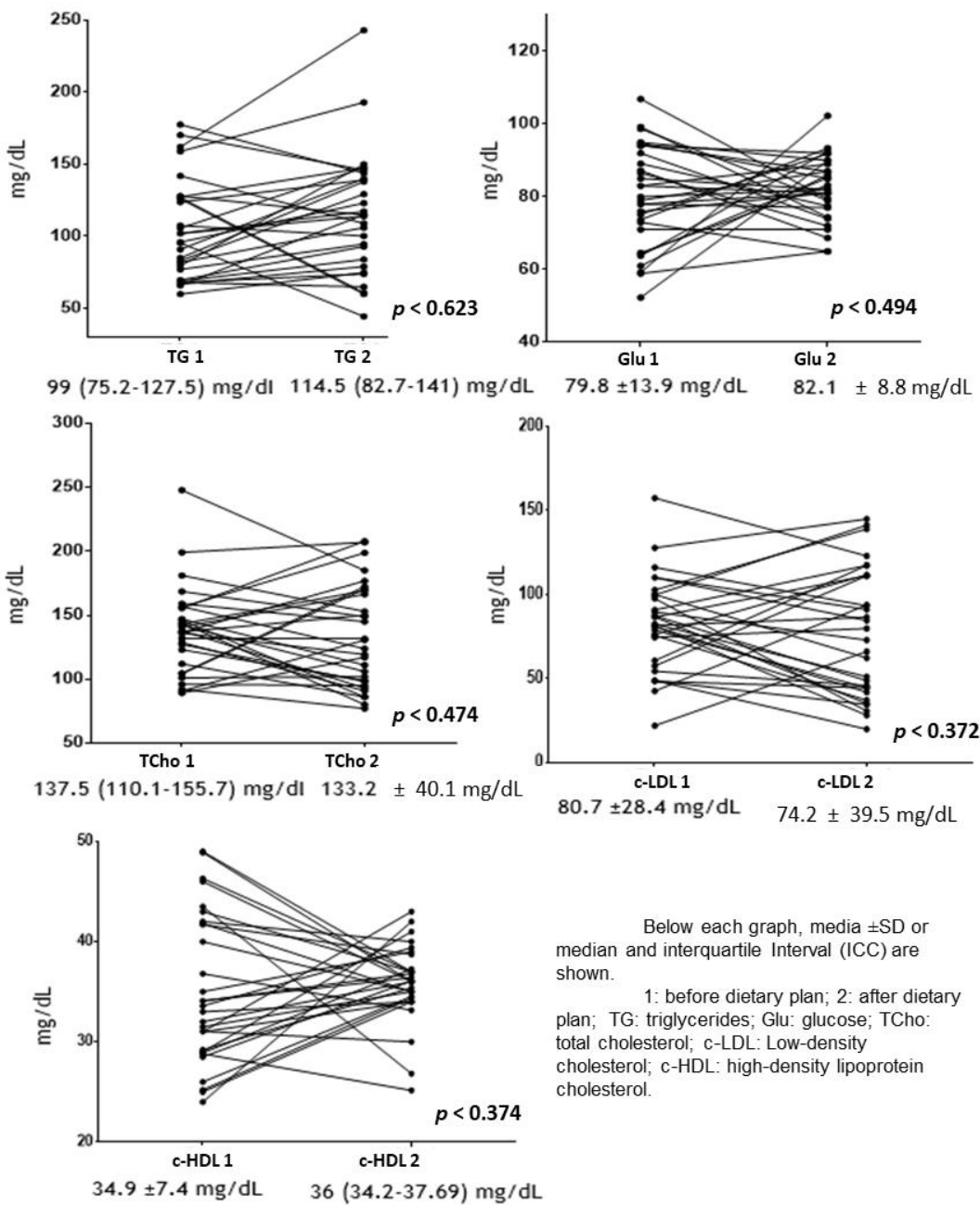

Figure 2. Changes in biochemical indicators before and after dietary plan. 
In relation to anthropometric and $\mathrm{BC}$ measurements after intervention in participants with $\mathrm{OW}$ and $\mathrm{Ob}$, it was found that nearly all variables statistically diminished as follows: WC $(p<0.001)$, ST $(p<0.001)$, BFM $(p<0.025)$, VAT $(p<0.020)$, and weight $(p<0.001)$; only the $\mathrm{kg}$ of the SMM was maintained (Table 2 ). In Figure 3, change $(\Delta)$ in those previously mentioned variables can be observed in each participant after implementation of the dietary plan.

After analyzing individual results, an improvement in BMI was observed: four persons with $\mathrm{Ob}$ became OW and two persons with OW became normal weight. In addition, two persons with visceral obesity became normal (data not shown).
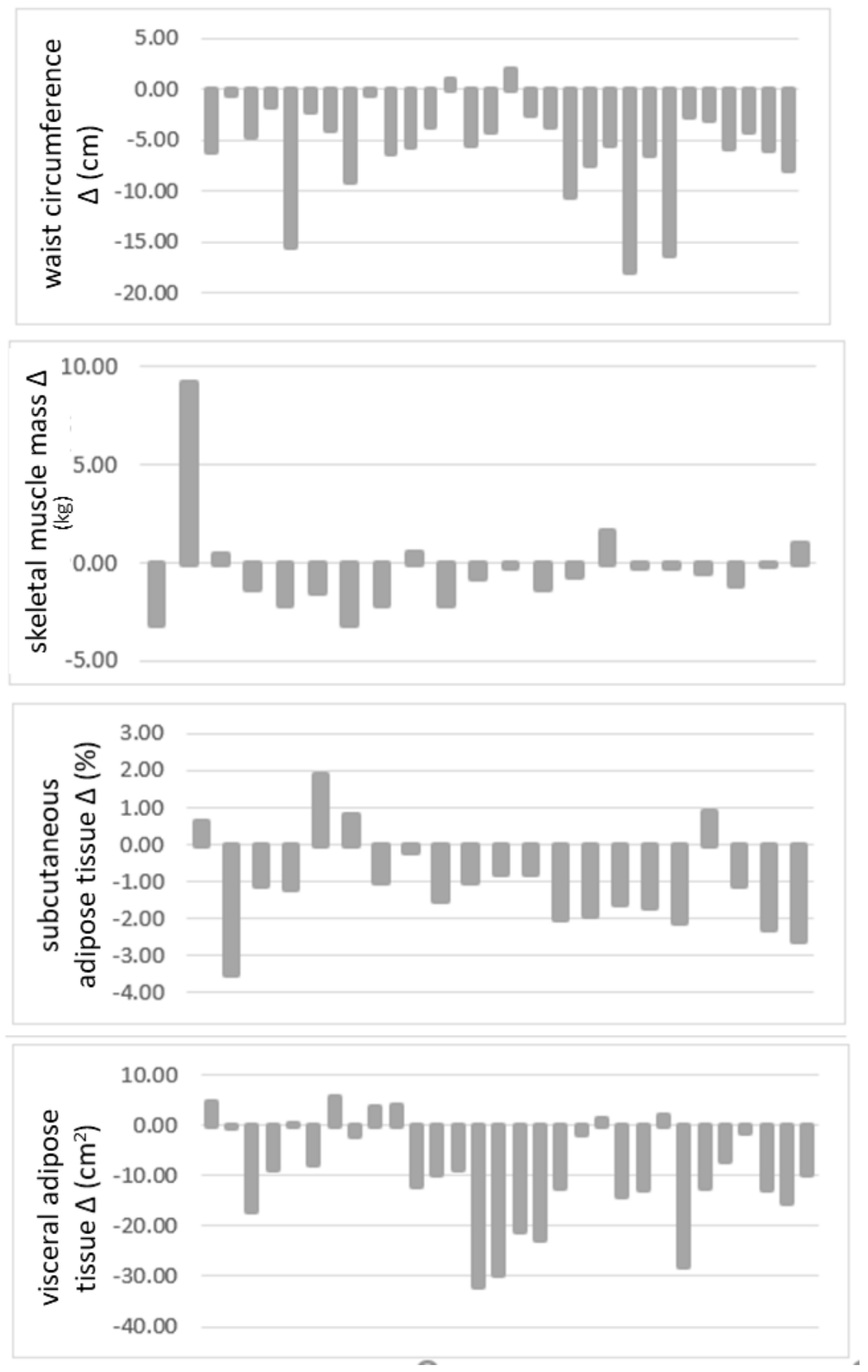

Figure 3. Changes in anthropometric and body composition measurements after the intervention. 


\subsection{Leukocyte Subpopulations after Intervention}

After dietary plan, it was observed in all participants that total lymphocytes and double-positive TCD4+ (TCD4+CD45RA+CD45RO+) cells diminished, while TCD3+ lymphocytes increased. All these changes were statistically significant. The remaining subpopulations presented no changes (data not shown).

On performing the analysis according to BMI, it was found that in persons with OW, total lymphocytes diminished and granulocytes increased after intervention. These differences were statistically significant. Double-positive TCD4+ (TCD4+CD45RA+CD45RO+) presented a tendency to diminish in persons with OW; however, where these indeed diminished significantly was in persons with $\mathrm{Ob}$. In addition, a significant increase in TCD3+ and TCD4+CD45RO+ (memory) lymphocytes and B lymphocytes' tendency to diminish were found in persons with $\mathrm{Ob}$ (Table 3).

\subsection{Partial Correlations and Linear Regressions after Intervention}

Partial correlations were obtained through the relation between changes $(\Delta)$ observed in leukocyte cells; upon performing the analysis according to BMI, it was found that in persons with OW, total lymphocytes diminished and granulocytes increased after intervention. These differences were statistically significant. Double-positive TCD4+ (TCD4+CD45RA+CD45RO+) presented a tendency to diminish in persons with OW; however, where these indeed diminished significantly was in persons with $\mathrm{Ob}$. In addition, a significant increase in TCD3+ and TCD4+CD45RO+ (memory) lymphocytes and B lymphocytes' tendency to diminish were found in persons with $\mathrm{Ob}$ (Table 3).

There were $\Delta$ in anthropometric, biochemical, and body composition variables after intervention. The analysis was adjusted by sex, age, and BMI. It was found that $\Delta$ at peripheral level of monocytes correlated negatively with $\Delta$ in DBP but positively with $\Delta$ in ST, just as $\Delta$ in NK lymphocytes correlated positively with $\Delta$ in TG. A negative correlation was found between $\Delta$ in TCD4+ helper lymphocytes (TCD4+CD62-, effector) and TCD4+ lymphocyte memory cells (TCD4+CD45RO+) and $\Delta$ in WC and glucose, respectively. A positive correlation was also observed between $\Delta$ in TCD8+ cytotoxic lymphocytes (TCD8+CD28-, effectors) and $\Delta$ in ST, and between $\Delta$ in TCD4+ virgin lymphocytes (TCD4+CD45RA+) and $\Delta$ in TCho, c-LDL, and WC. All these correlations were significant (Table 4).

Table 4. Partial correlations and linear regressions after intervention between leucocytes and biochemical indicators, anthropometric measurements and body composition.

\begin{tabular}{cccc}
\hline Leukocyte Cells (\%) & Variables & $p$ & $p$ \\
\hline Monocytes $\Delta$ & DBP $\Delta(\mathrm{mmHg})$ & -0.555 & $0.003^{*}$ \\
Lymphocytes B $\Delta$ & ST $\Delta(\%)$ & 0.588 & $0.013^{*}$ \\
Lymphocytes NK $\Delta$ & c-LDL $\Delta(\mathrm{md} / \mathrm{dL})$ & 0.370 & 0.069 \\
Lymphocytes T CD4+ $\Delta$ & TG $\Delta(\mathrm{md} / \mathrm{dL})$ & 0.431 & $0.032^{*}$ \\
& c-HDL $\Delta(\mathrm{md} / \mathrm{dL})$ & 0.339 & 0.090 \\
Lymphocytes T CD4+CD62- $\Delta$ & ST $\Delta(\%)$ & -0.446 & 0.073 \\
Lymphocytes T CD8+CD28- $\Delta$ & WC $\Delta(\mathrm{cm})$ & -0.553 & $0.026^{*}$ \\
& TG $\Delta(\mathrm{md} / \mathrm{dL})$ & 0.365 & 0.056 \\
T CD4+CD45RA+ $\Delta$ & ST $\Delta(\%)$ & 0.721 & $0.028^{*}$ \\
& TCho $\Delta(\mathrm{md} / \mathrm{dL})$ & 0.487 & $0.030^{*}$ \\
T CD4+CD & WC $\Delta(\mathrm{md} / \mathrm{dL})$ & 0.474 & $0.035^{*}$ \\
CD4+CD45RO+CD45RA+ $\Delta$ & c-HDL $\Delta(\mathrm{md} / \mathrm{dL})$ & 0.575 & $0.008^{*}$ \\
\hline
\end{tabular}

DBP: diastolic blood pressure; ST: subcutaneous adipose tissue; c-LDL: low-density cholesterol; TG: triglycerides ; c-HDL: high-density lipoprotein cholesterol; WC: waist circumference; Total Cho: total cholesterol; BFM: body fat mass. $p$ : $p$ value adjusted by gender, age and BMI $(*: p<0.05)$. 
Based on the results above, we decided to carry out a linear regression adjusted by sex, age, and BMI, between $\Delta$ in leukocyte subpopulations that correlated statistically and $\Delta$ in anthropometric, biochemical, and BC variables. A positive correlation was found between $\Delta$ in monocytes and $\Delta$ in ST, where a $1 \%$ decrease in this tissue is associated with a $1.5 \%$ (range, 0.3-2.6) decrease in monocytes (Figure 4).
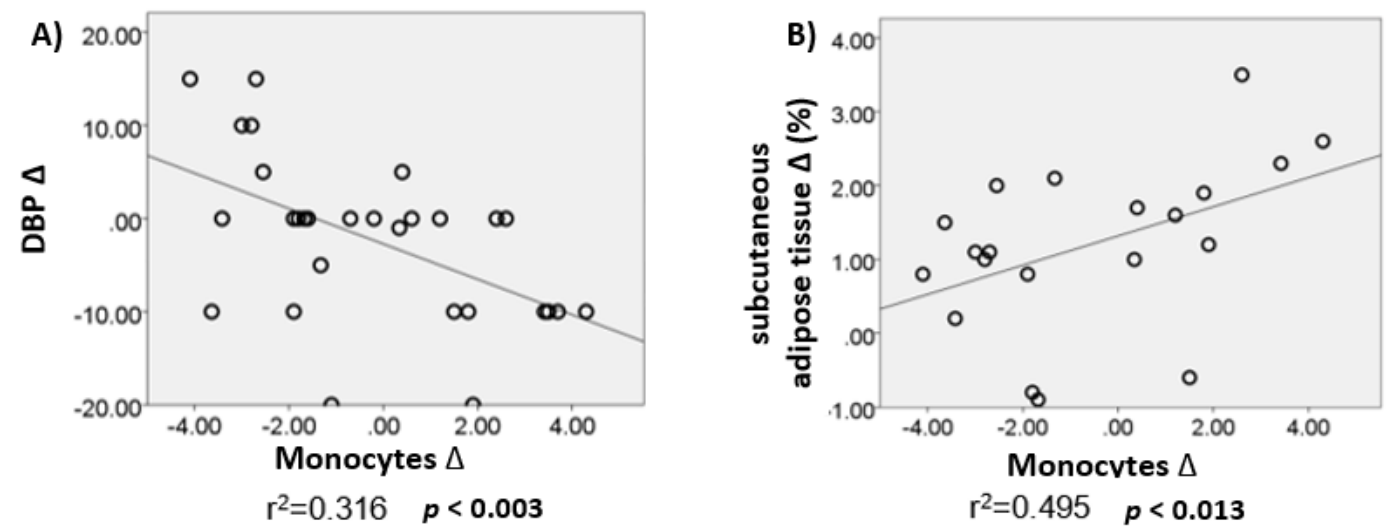

Coeficiente de correlación: -2.039 [95\% $\mathrm{Cl}-3.327,-0.751]$ Coeficiente de correlación: 0.228 [95\% $\mathrm{Cl} 0.055,0.401]$

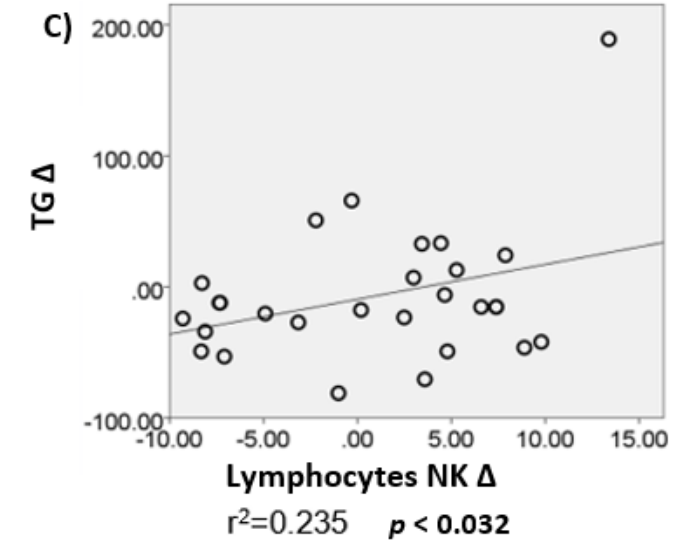

Coeficiente de correlación: 3.450 [95\% $\mathrm{Cl} 0.331,6.568]$

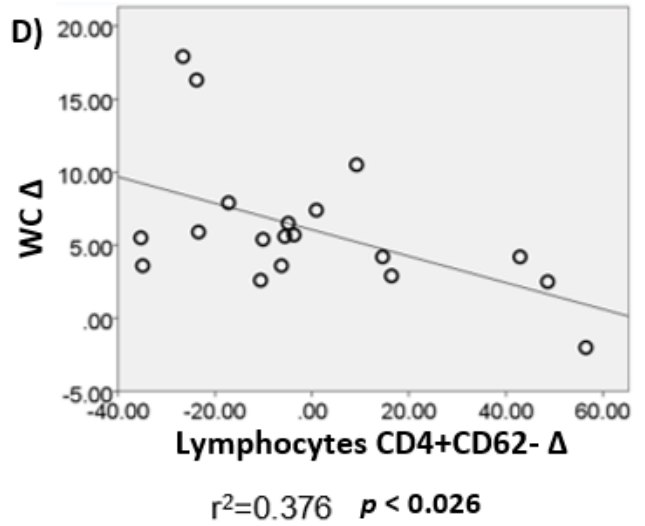

Coeficiente de correlación: $-0.092[95 \% \mathrm{Cl} 0.172,-0.013]$

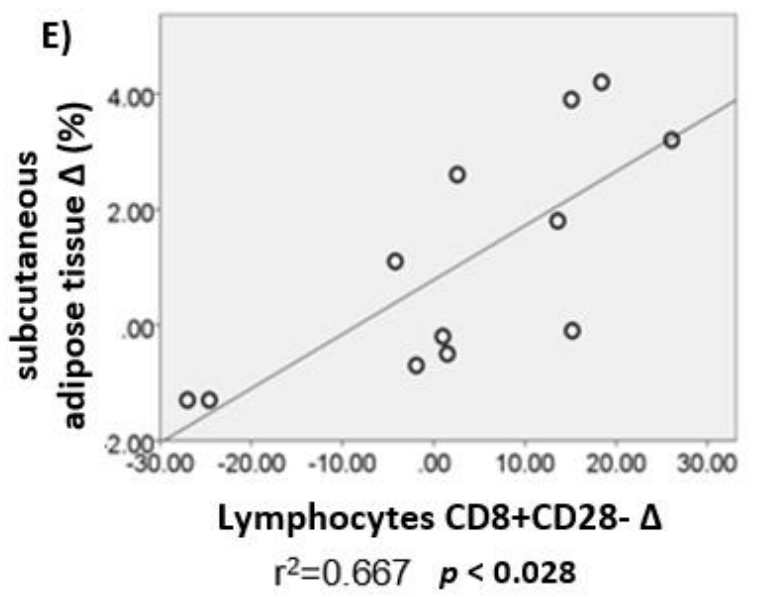

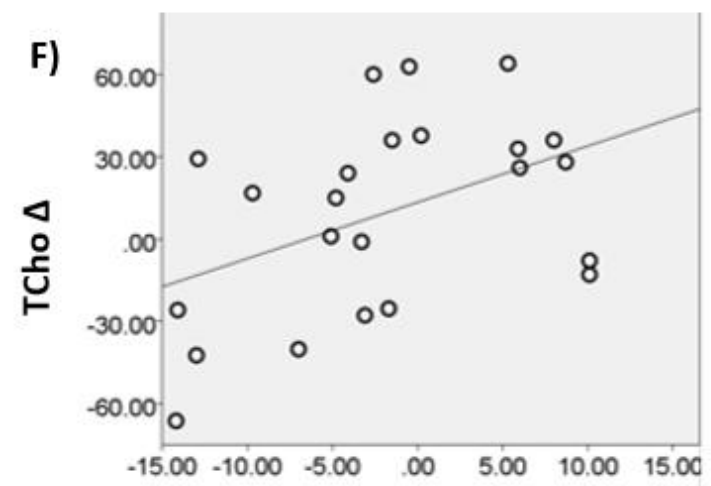

Lymphocytes CD4+CD45RA+ $\Delta$

$$
r^{2}=0.406 p<0.030
$$

Coeficiente de correlación: 0.080 [95\% $\mathrm{Cl} 0.011,0.148$ ] Coeficiente de correlación: 2.204 [95\% Cl 0.245, 4.163]

Figure 4. Cont. 


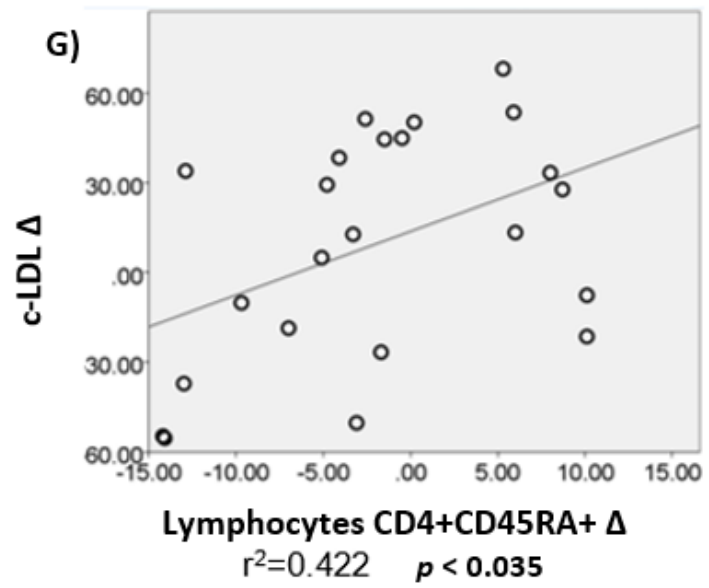

Coeficiente de correlación: 2.240 [95\% $\mathrm{Cl} 0.182,4.298]$

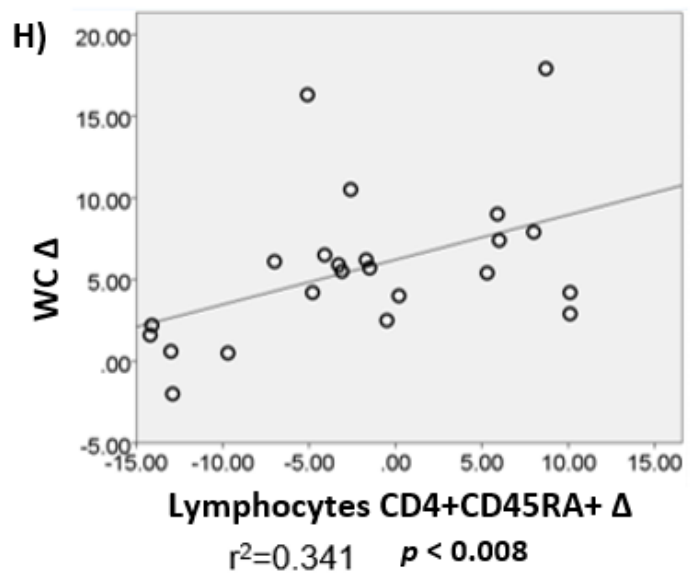

Coeficiente de correlación: $0.378[95 \% \mathrm{Cl} 0.111,0.645]$

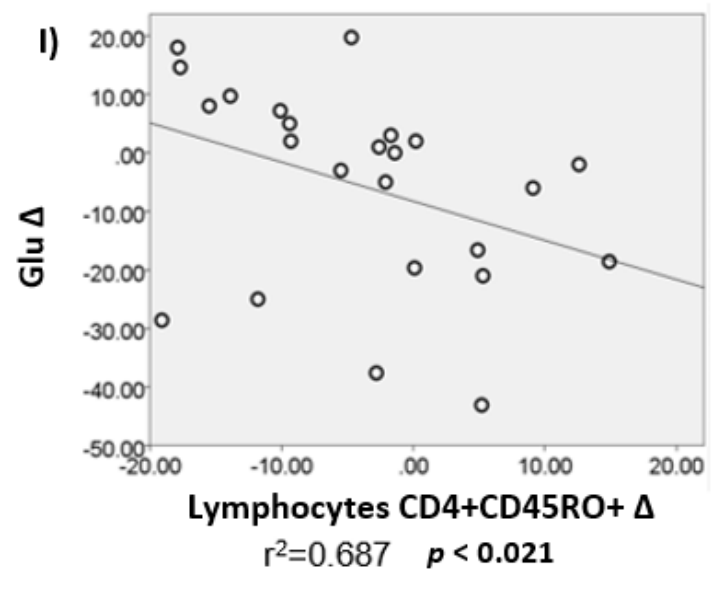

Coeficiente de correlación: $-0.648[95 \% \mathrm{Cl}-1.186,-0.111]$

Figure 4. Linear regression between delta in leucocyte cells and delta in anthropometric, biochemical and body composition variables. (A) Lineal regression between DBP $\Delta$ vs monocytes $\Delta$; (B) Lineal regression between ST $\Delta$ vs monocytes $\Delta$; (C) Lineal regression between TG $\Delta$ vs lymphocytes $\Delta$; (D) Lineal regression between WC $\Delta$ vs Lymphocytes CD4+CD62- $\Delta$; (E) Lineal regression between TS $\Delta$ vs Lymphocytes CD8+CD28- $\Delta$; (F) Lineal regression between TCho $\Delta$ vs Lymphocytes CD4+CD45RA $+\Delta ;(G)$ Lineal regression between c-LDL $\Delta$ vs Lymphocytes CD4+CD45RA $+\Delta ;(H)$ Lineal regression between WC $\Delta$ vs Lymphocytes CD4+CD45RA $+\Delta$; (I) Lineal regression between Glu $\Delta$ vs Lymphocytes CD4+CD45RO+ $\Delta$. DBP: diastolic blood pressure; TG: triglycerides; WC: waist circumference; TCho: total cholesterol; c-LDL: Low-density cholesterol; Glu: glucose; ST: subcutaneous adipose tissue. $p$ value adjusted by sex, age and BMI $(p<0.05)$.

$\Delta$ in TCD8+CD28- lymphocytes also correlated positively with $\Delta$ in ST, where a $1 \%$ decrease in this tissue was associated with a 6.5\% (range, 1-12) decrease in effector lymphocytes (TCD8+CD28-). On the other hand, $\Delta$ in TCD4+CD62- effector lymphocytes correlated negatively with $\Delta$ in WC, where a $1 \mathrm{~cm}$ decrease in WC was associated with a 3\% (range, 6-0.4) decrease in TCD4+CD62- lymphocytes. All these data were statistically significant. In Figure 4, all linear regressions with their squared $\mathrm{r}$ can be observed.

\section{Discussion}

A poor-quality diet contributes to health adversities, among them overweight and obesity, as well as the comorbidities they entail. Over the last decades years, the population has consumed "unhealthy diets", characterized by a low intake of fruits, vegetables, seeds, and fish, and a high intake of red meat, processed foods, saturated fats, and sugars in all presentations, which has been associated with an increase in the prevalence of $\mathrm{OW}$ and $\mathrm{Ob}$, 
as well as with deaths caused by heart diseases, heart attacks, and type 2 diabetes mellitus (DM2) [40].

This study focused on observing the impact of the DASH diet on leukocyte subpopulations, and biochemical, anthropometric, and body composition parameters, in persons with $\mathrm{OW}$ and $\mathrm{Ob}$.

After 8 weeks under this dietary plan, biochemical variables revealed no significant changes either in the general population or in comparison with BMI. However, when the analysis of each participant was conducted, it was found that TG, glucose, total cholesterol, and LDL-c lowered their blood levels by $30 \pm 15 \%$, and HDL-c increased by $6.9 \pm 4.4 \%$ (in approximately $52 \%$ of participants). These data show similarities with those reported by a study in adults with OW and $\mathrm{Ob}$, who adhered to a DASH diet for 3 weeks. These individuals experienced a decrease in total cholesterol, LDL-c, and HDL-c [41]. Similarly, in a longitudinal study carried out in middle-aged women, adherence to the DASH diet was associated with a low risk of cardiovascular disease and heart attacks [42]. In addition, a study in adults with $\mathrm{OW}$ and $\mathrm{Ob}(n=3218$, age $39.2 \pm 9.5)$ found that greater adherence to the DASH-style dietary pattern was related to better metabolic profiles [43].

Regarding anthropometric and body composition measurements, we found significant changes in nearly all variables (weight, WC, ST, BFM and VAT). In addition, as previously mentioned, six persons decreased their BMI and two persons decreased their VAT to normality. These data coincide with a study conducted in women (30-40 years, $n=60)$ with $\mathrm{OW}$ and $\mathrm{OB}$ and polycystic ovary syndrome, where participants lost a significant amount of weight, BMI and body fat [44]. Along these lines, another study in individuals with OW and $\mathrm{Ob}$ (age $61.34 \pm 7.9, n=131$ ) and primary arterial hypertension found that weight, BMI, WC, and percentage and kilograms of subcutaneous adipose tissue decreased after a 3-month intervention with the DASH diet, although this group had older participants and a longer intervention period than ours [45].

The nutritional intervention carried out in the present study, with a decreased energy intake, was conducted without any additional physical activity in order to assess solely the role of a well-balanced diet in persons with $\mathrm{OW}$ and $\mathrm{Ob}$. Important changes in body composition were found, above all in weight and fat loss and mainly in visceral fat (considering that visceral fat is metabolically more active in comorbidities associated with obesity). Therefore, the present results reaffirm the importance of a personalized diet for achieving positive changes in body composition and mainly for VAT loss, which maintains a close relation with the presence of immunological alterations that have repercussions on metabolism [33].

It has been studied how intake of specific nutrients has changed inflammatory parameters in blood and provided a quantitative estimate of the inflammatory tendency of an individual's diet [11]. In a similar way, feeding affects the nutritional status of individuals, which, in turn, affects the inflammatory response of the immune system. Therefore, malnutrition leads to immunosuppression due to an increased susceptibility to infection, while over-nutrition leads to immunoactivation due to an increased susceptibility to inflammatory conditions [46]. On such basis, we decided to observe the impact of a DASH diet on different leukocyte subpopulations.

In this study, once immune cells were analyzed according to BMI, it was found that total lymphocytes decreased and granulocytes increased only in persons with OW, while TCD3+ lymphocytes and TCD4+ (TCD4+CD45RO+) memory cells increased and doublepositive cells TCD4+ (TCD4+CD45RA+CD45RO+) decreased in persons with obesity, thus finding leukocyte mobilization at the differential peripheral level according to BMI.

It was also found that, prior to intervention, participants had increased TCD3+ and TCD4+ (CD45RO+) memory cells. This cell type has been related to a low intensity chronic inflammatory process in persons with obesity [33]; thus, it was expected that these cells would decrease; however, they remained unchanged. Memory T cells are produced through the stimuli of antigens, which, in persons with $\mathrm{Ob}$, are due to the presence of free fatty acids, driving the rise in long-lasting cell population [47]. 
As above, it has been studied that in persons with $\mathrm{OW}$ and $\mathrm{Ob}$, the latter present an imbalance between memory cells (increased) and naïve cells (decreased), which has been associated with premature immunosenescence. Such imbalance and its effect on the immune system is similar to that in older adults $[33,48]$, which limits the host's ability to mount responses to new antigenic challenge [49]. Another finding of our study with young adults was a moderate increase in naïve cells in persons with OW, perhaps indicating a better immunological balance, as these cells are important to respond to new agents and produce a response toward their elimination [50].

To our best knowledge, there are few studies on the immunological implications of feeding in general in persons with excess weight. A study carried out in 1500 adults (aged 50-69) with OW and $\mathrm{Ob}$ found an association between feeding quality (based on the scoring of the DASH diet) and cardiometabolic health markers (a leukocyte count among them). In such study, an inverse association was found between the quality of the DASH diet and the leukocyte count; that is, the higher the score on the DASH diet, the lower the leukocyte count [40], which could be related to the decrease in total lymphocytes found in the present study in individuals with OW-in this case, young adults. Another study reported that a predominance of foods high in cholesterol and saturated fats and relatively low amounts of fruits and vegetables increased inflammation in participants, evidenced by the increase in blood levels of IL-6, homocysteine, and the leukocyte count [13].

It is known that the incorporation of more vegetables, fruits, fish, omega 3 polyunsaturated fats, fiber, and whole grains in the diet (for example, the Mediterranean diet, the macrobiotic diet, etc.) drives the anti-inflammatory potential in persons for whom these foods constitute their habitual diet [12]. These characteristics are shared by the DASH diet, and the changes found in lymphocyte subpopulations could be related to the decrease in the pro-inflammatory process present in this type of person.

It is noteworthy that a $1 \%$ decrease in adipose tissue (AT) is associated with a decrease of about $1.5 \%$ in monocytes and of $6.5 \%$ in TCD8+CD28- lymphocytes, while a $1 \mathrm{~cm}$ decrease in WC is associated with a 3\% (range, 6-0.4) decrease in TCD4+CD62-lymphocytes (both phenotypes are effector cells). These changes express the impact of diet on body composition and the inflammatory process present in persons with $\mathrm{OW}$ and $\mathrm{Ob}$, given that monocytes as well as effector cells have been observed in diverse studies to directly correlate with the degree of metabolic dysfunction in patients with obesity, as these cells provide a link between inflammation in VAT (as well as systemic inflammation) and insulin resistance (IR) through the activation of distinct pro-inflammatory signaling pathways [51,52].

It has been reported that diet plays a central role in the regulation of chronic inflammation [12,15]; however, these are relatively new works, and little has been studied on the pro-inflammatory effect that these interventions have on persons with overweight and obesity. In addition, it has been shown that dietary components have a much broader safety margin than habitual intake of anti-inflammatory pharmaceuticals [12]. Therefore, it is important to continue to work on dietary habits in persons with $\mathrm{OW}$ and $\mathrm{Ob}$, as there is evidence, reported by other investigations and supported by the present one, of a positive effect of healthy diets on inflammation variables, as well as on anthropometric, body composition, and biochemical variables.

\section{Conclusions}

It was found that the DASH diet gives rice to positive changes in peripheral immune cells, anthropometric parameters and body composition. In addition, the study found that total lymphocytes and double-positive (TCD4+CD45RO+CD45RA+) cells decreased and TCD3+ lymphocytes increased after intervention. Changes in subpopulations (monocytes, NK lymphocytes, helper, cytotoxic, and naive cells) were related with improvements in glucose, total cholesterol, LDL-c, TG, WC, and ST. These findings could be related with immunological improvement in these patients. 
The present study confirms that the DASH diet is a good proposal for nutritious intervention in the treatment of obesity as it improves the chronic inflammatory process, preventing metabolic alterations that could occur in these patients.

Author Contributions: Conceptualization, C.P.R.-L. and O.N.-M.; methodology, C.P.R.-L. and O.N.M.; formal analysis, C.P.R.-L. and O.N.-M.; investigation, C.P.R.-L. and O.N.-M.; writing-original draft preparation, C.P.R.-L. and O.N.-M.; writing-review and editing, C.P.R.-L., M.C.G.-T., C.A.A.-S. and O.N.-M. All authors have read and agreed to the published version of the manuscript.

Institutional Review Board Statement: The study was conducted according to the guidelines of the Declaration of Helsinki, and approved by the Ethics Committee and the Divisional Council of Biological and Health Sciences of the UAM-Xochimilco in Session 13/16, held on 1 December 2016.

Informed Consent Statement: Informed consent was obtained from all subjects involved in the study.

Acknowledgments: The authors acknowledge LN María Magdalena Rodríguez-Magallanes for technical support, as well as the National Council of Science and Technology (CONACYT, México) for a postgraduate studies scholarship awarded to Carmen Paulina Rodríguez-López (371434).

Conflicts of Interest: The authors declare that do not have any conflicts of interest.

\section{References}

1. Roumans, N.J; Vink, R.G.; Fazelzadeh, P.; van Baak, M.A.; Mariman, E.C. A role for leukocyte integrins and extracellular matrix remolding of adipose tissue in the risk or weight regain after weight loss. Am. J. Clin. Nutr. 2017, 105, 1054-1062. [CrossRef] [PubMed]

2. Zatterale, F.; Longo, M.; Naderi, J.; Raciti, G.A.; Desiderio, A.; Miele, C.; Beguinot, F. Chronic adipose tissue inflammation linking obesity to insulin resistance and type 2 diabetes. Front. Physiol. 2020, 10, 1607. [CrossRef] [PubMed]

3. Anderson, E.K.; Gutierrez, D.A.; Kennedy, A.; Hasty, A.H. Weight cycling increases T-cell Accumulation in adipose tissue and impairs systemic glucose tolerance. Diabetes 2013, 62, 3180-3188. [CrossRef] [PubMed]

4. Esser, N.; Legrand-Poels, S.; Piette, J.; Scheen, A.J.; Paquot, N. Inflammation as a link between obesity, metabolic syndrome and type 2 diabetes. Diabetes Res. Clin. Pr. 2014, 105, 141-150. [CrossRef] [PubMed]

5. Ryder, E.; Diez-Ewald, M.; Mosquera, J.; Fernández, E.; Pedreanez, A.; Vargas, R.; Peña, C.; Fernández, N. Association of obesity with leukocyte count in obese individuals without metabolic syndrome. Diabetes Metab. Syndr. Clin. Res. Rev. 2014, 8, 197-204. [CrossRef] [PubMed]

6. Donninelli, G.; del Cornò, M.; Pierdominici, M.; Scazzocchio, B.; Varì, R.; Varano, B.; Pacella, I.; Piconese, S.; Barnaba, V.; D'Archivio, M.; et al. Distinct blood and visceral adipose tissue regulatory $\mathrm{T}$ cell and innate lymphocyte profiles characterize obesity and colorectal cancer. Front. Immunol. 2017, 8, 643. [CrossRef] [PubMed]

7. Liu, R.; Nikolajczyk, B.S. Tissue inmmune cells fuel obesity-associated inflammation in adipose tissue and beyond. Front. Immunol. 2019, 10, 1587. [CrossRef]

8. Manzur, F; Alvear, C.; Alayón, A.N. Adipocytes, visceral obesity, inflammation and cardiovascular disease. Rev. Colomb. Cardiol. 2010, 17, 207-213.

9. Coelho, M.; Oliveira, T.; Fernandes, R. Biochemistry of adipose tissue: An endocrine organ. Arch. Med. Sci. 2013, 9, 191-200. [CrossRef]

10. Marette, A.; Liu, Y.; Sweeney, G. Skeletal muscle glucose metabolism and inflammation in the development of the metabolic syndrome. Rev. Endocr. Metab. Disord. 2014, 15, 299-305. [CrossRef]

11. Muhammad, H.F.L.; Vink, R.G.; Roumans, N.J.T.; Arkenbosch, L.A.J; Mariman, E.C.; Van Baak, M.A. Dietary intake after weight loss and the risk of weight regain: Macronutrient composition and inflammatory properties of the diet. Nutrients 2017, 9, 1205. [CrossRef] [PubMed]

12. Steck, S.; Shivappa, N.; Tabung, F.K.; Harmon, B.E.; Wirth, M.D.; Hurley, T.G.; Hebert, J.R. The dietary inflammatory index: A new tool for assessing diet quality based on inflammatory potential. Digest 2014, 49, 1-9.

13. Shivappa, N.; Hébert, J.R.; Rietzschel, E.R.; De Buyzere, M.L.; Langlois, M.; Debruyne, E.; Marcos, A.; Huybrechts, I. Associations between dietary inflammatory index and inflammatory markers in the Asklepios study. Br. J. Nutr. 2015, 113, 665-671. [CrossRef] [PubMed]

14. Wirth, M.D.; Hébert, J.R.; Shivappa, N.; Hand, G.A.; Hurley, T.G.; Drenowatz, C.; McMahon, D.; Shook, R.P.; Blair, S.N. Antiinflammatory dietary inflammatory index scores are associated with healthier scores on other dietary indices. Nutr. Res. 2016, 36, 214-219. [CrossRef] [PubMed]

15. Shivappa, N.; Steck, S.E.; Hurley, T.G.; Hussey, J.R.; Hébert, J.R. Designing and developing a literature-derived, population-based dietary inflammatory index. Public Health Nutr. 2013, 17, 1689-1696. [CrossRef]

16. Sociedad Argentina de Hipertensión Arterial (Arterial Hypertension Argentine Society). (SAHA). Dieta DASH. 2010. Available online: http:/ / www.saha.org.ar/dieta-dash.php (accessed on 5 June 2021). 
17. Ahluwalia, N.; Andreeva, V.; Kesse-Guyot, E.; Hercberg, S. Dietary patterns, inflammation and the metabolic syndrome. Diabetes Metab. 2013, 39, 99-110. [CrossRef]

18. Appel, L.J.; Moore, T.J.; Obarzanek, E.; Vollmer, W.M.; Svetkey, L.P.; Sacks, F.M.; Bray, G.A.; Vogt, T.M.; Cutler, J.A.; Windhauser, M.M.; et al. A clinical trial of the effects of dietary patterns on blood pressure. N. Engl. J. Med. 1997, 336, 1117-1124. [CrossRef]

19. Azadbakht, L.; Surkan, P.J.; Esmaillzadeh, A.; Willett, W.C. The dietary approaches to stop hypertension eating plan affects c-reactive protein, coagulation abnormalities, and hepatic function tests among type 2 diabetic patients. J. Nutr. 2011, 141, 1083-1088. [CrossRef]

20. Fitzgerald, K.C.; Chiuve, S.; Buring, J.E.; Ridker, P.M.; Glynn, R.J. Comparison of associations of adherence to a dietary approaches to stop hypertension (DASH)-style diet with risks of cardiovascular disease and venous thromboembolism. J. Thromb. Haemost. 2011, 10, 189-198. [CrossRef]

21. Valentino, G.; Tagle, R.; Acevedo, M. DASH diet and menopause: Beyond the benefits on control of blood pressure. Rev. Chil. Cardiol. 2014, 33, 215-222. [CrossRef]

22. Medina-Remón, A.; Kirwan, R.; Lamuela-Raventós, R.M.; Estruch, R. Dietary patterns and the risk of obesity, type 2 diabetes mellitus, cardiovascular diseases, asthma, and neurodegenerative diseases. Crit. Rev. Food Sci. Nutr. 2016, 58, 262-296. [CrossRef]

23. Hill, A.M.; Harris Jackson, K.A.; Roussell, M.A.; West, S.G.; Kris-Etherton, P.M. Type and amount of dietary protein in the treatment of metabolic syndrome: A randomized controlled trial. Am. J. Clin. Nutr. 2015, 102, 757-770. [CrossRef]

24. Kawamura, A.; Kajiya, K.; Kishi, H.; Inagaki, J.; Mitarai, M.; Oda, H.; Umemoto, S.; Kobayashi, S. Effects of the DASH-JUMP dietary intervention in Japanese participants with high-normal blood pressure and stage 1 hypertension: An open-label single-arm trial. Hypertens. Res. 2016, 39, 777-785. [CrossRef]

25. Soltani, S.; Shirani, F.; Chitsazi, M.J.; Salehi-Abargouei, A. The effect of dietary approaches to stop hypertension (DASH) diet on weight and body composition in adults: A systematic review and meta-analysis of randomized controlled clinical trials. Obes. Rev. 2016, 17, 442-454. [CrossRef]

26. Marfell-Jones, M. International Society for the Advancement of Kyneanthropometry I. In International Standards for an-Thropometric Assessment; International Society for the Advancement of Kyneanthropometry: Glasgow, Scotland, 2006; pp. 73-88.

27. Secretariat of Health of Mexico City. Overweight and Obesity. 2014. Available online: http://www.salud.df.gob.mx/ssdf/index php?option=com_content\&task=view\&id=4034 (accessed on 7 April 2014).

28. World Health Organization (WHO). 10 Datos Sobre la Obesidad (10 Facts about Obesity). 2015. Available online: www.who.int/ features/factfiles/obesity/facts/es/ (accessed on 20 July 2015).

29. Biospace Co., Ltd. InBody720: The Precision Body Composition Analyzer: User's Manual; Biospace Co., Ltd.: Seoul, Korea, 1996-2005; pp. 135-784.

30. NOM-030-SSA2-2009 NOM. Official Mexican Standard. For the Prevention, Detection, Diagnosis, Treatment and Control of Arterial Hypertension. Available online: http:/ / dof.gob.mx/nota_detalle.php?codigo=5144642\&fecha=31/05/2010 (accessed on 23 April 2021).

31. Albornoz Lopez, R.; Perez Rodrigo, I. Nutrition and metabolic síndrome. Nutr. Clín. Diet. Hosp. 2012, $32,92-97$.

32. Nájera-Medina, O.; Valencia-Chavarría, F.; Cortés-Bejar, C.; Palacios-Martínez, M.; Rodríguez-López, C.P.; González-Torres, M.C. Infected malnourished children displayed changes in early activation and lymphocyte subpopulations. Acta Paediatr. 2017, 106, 1499-1506. [CrossRef] [PubMed]

33. Rodríguez, C.P.; Gonzalez, M.C.; Aguilar-Salinas, C.A.; Nájera-Medina, O. Peripheral lymphocytes, obesity, and metabolic syndrome in young adults: An immunometabolism study. Metab. Syndr. Relat. Disord. 2018, 16, 342-349. [CrossRef] [PubMed]

34. Levy, T.; Villalpando, S.; Rivera, J. Nutrition results of the Mexican National Health and Nutrition Survey. 2006. Available online: https://www.scielosp.org/article/spm/2009.v51suppl4/S492-S493/ (accessed on 4 October 2021).

35. Hernández-Avila, M.; Romieu, I.; Parra, S.; Hernandez-Avila, J.E.; Madrigal, H.; Willett, W. Validity and reproducibility of a food frequency questionnaire to assess dietary intake of women living in Mexico City. Salud Pública México 1998, 40, 133-140. [CrossRef]

36. Kathleen, L.; Escott-Stump, S. Krause Dietoterapia, 12th ed.; Elsevier España, S.L.U.: Barcelona, Spain, 2009.

37. Pérez-Lizaur, A.B.; Palacios González, B.; Castro Becerra, A.L.; Flores-Galicia, I. Sistema Mexicano de Alimentos Equivalentes (Mexican Equivalent Food System); FNS: Monterrey, Mexico, 2014; 160p.

38. Challa, H.J.; Ameer, M.A.; Uppaluri, K.R. DASH Diet to Stop Hypertension; StatPearls Publishing: Treasure Island, FL, USA, 2014.

39. Asemi, Z.; Esmaillzadeh, A. DASH diet, insulin resistance, and serum hs-CRP in polycystic ovary syndrome: A randomized controlled clinical trial. Horm. Metab. Res. 2015, 47, 232-238. [CrossRef]

40. Phillips, C.M.; Harrington, J.M.; Perry, I.J. Relationship between dietary quality, determined by DASH score, and cardiometabolic health biomarkers: A cross-sectional analysis in adults. Clin. Nutr. 2019, 38, 1620-1628. [CrossRef]

41. Chiu, S.; Bergeron, N.; Williams, P.T.; Bray, G.A.; Sutherland, B.; Krauss, R.M. Comparison of the DASH (Dietary Approaches to Stop Hypetension) diet and higher-fat DASH diet on blood pressure and lipids and lipoproteins: A rendomized controlled trial. Am. J. Clin. Nutr. 2016, 103, 341-347. [CrossRef]

42. Fung, T.T.; Chiuve, S.E.; McCullough, M.L.; Rexrode, K.M.; Logroscino, G.; Hu, F.B. Adherence to a DASH-style diet and risk of coronary heart disease and stroke in women. Arch. Intern. Med. 2008, 168, 713-720. [CrossRef] 
43. Farhadnejad, H.; Darand, M.; Teymoori, F.; Asghari, G.; Mirmiran, P.; Azizi, F. The association of Dietary Approach to Stop Hypertension (DASH) diet with metabolic healthy and metabolic unhealthy obesity phenotypes. Sci. Rep. 2019, 9, 1869. [CrossRef] [PubMed]

44. Azadi-Yazdi, M.; Karimi-Zarchi, M.; Salehi-Abargouei, A.; Fallahzadeh, H.; Nadjarzadeh, A. Effects of dietary approach to stop hypertension diet on androgens, antioxidant status and body composition in overweight and obese women with polycystic ovary syndrome: A randomised controlled trial. J. Hum. Nutr. Diet. 2016, 30, 275-283. [CrossRef] [PubMed]

45. Kucharska, A.; Gajewska, D.; Kiedrowski, M.; Sińska, B.; Juszczyk, G.P.; Czerw, A.; Augustynowicz, A.; Bobiński, K.; Deptała, A.; Niegowska, J. The impact of individualised nutritional therapy according to DASH diet on blood pressure, body mass, and selected biochemical parameters in overweight/obese patients with primary arterial hypertension: A prospective randomised study. Kardiol. Pol. 2018, 76, 158-165. [CrossRef] [PubMed]

46. Lee, H.; Lee, I.S.; Choue, R. Obesity, inflammation and diet. Pediatr. Gastroenterol. Hepatol. Nutr. 2013, 16, 143-152. [CrossRef] [PubMed]

47. Mauro, C.; Smith, J.; Cucchi, D.; Coe, D.; Fu, H.; Bonacina, F.; Baragetti, A.; Cermenati, G.; Caruso, D.; Mitro, N.; et al. Obesityinduced metabolic stress leads to biased effector memory CD4+ T cell differentiation via PI3K p110delta-Akt-mediated signals. Cell Metab. 2017, 25, 593-609. [CrossRef]

48. Parisi, M.M.; Grun, L.K.; Lavandoski, P.; Alves, L.B.; Bristot, I.J.; Mattiello, R.; Mottin, C.C.; Klamt, F.; Jones, M.H.; Padoin, A.V.; et al. Immunosenescence induced by plasma from individuals with obesity caused cell signaling dysfunction and inflammation. Obesity 2017, 25, 1523-1531. [CrossRef]

49. Kanneganti, T.D.; Dixit, V.D. Immunological complications of obesity. Nat. Immunol. 2012, 13, 707-712. [CrossRef]

50. Mold, J.E.; Réu, P.; Olin, A.; Bernard, S.; Michaëlsson, J.; Rane, S.; Yates, A.; Khosravi, A.; Salehpour, M.; Possnert, G.; et al. Cell generation dynamics underlying naive T-cell homeostasis in adult humans. PLoS Biol. 2019, 17, e3000383. [CrossRef]

51. Pandolfi, J.B.; Ferraro, A.A.; Sananez, I.; Gancedo, M.C.; Baz, P.; Billordo, L.A.; Fainboim, L.; Arruvito, L. ATP-induced inflammation drives tissue-resident Th17 cells in metabolically unhealthy obesity. J. Immunol. 2016, 196, 3287-3296. [CrossRef] [PubMed]

52. Magrone, T.; Jirillo, E.; Spagnoletta, A.; Magrone, M.; Russo, M.A.; Fontana, S.; Laforgia, F.; Donvito, I.; Campanella, A.; Silvestris, F.; et al. Immune profile of obese people and in vitro effects of red grape polyphenols on peripheral blood mononuclear cells. Oxidative Med. Cell. Longev. 2017, 2017, 1-11. 